productivity, the authors elaborate the factors affecting it and the problems of measurement. To arrive at a true measure of effectiveness, it is necessary to make allowance not only for the number of personnel engaged in the unit under examination but also for the invisible men who serve the unit externally in the supply of the necessary capital equipment, raw materials and other services. Sir Ewart and Dr. Beeching also consider that Marshall Aid distorts the productivity picture. The present rate of this aid is equivalent to the wages of 750,000 industrial workers at current British wage rates, and since "the total number engaged in industrial production in Gt. Britain is some $10,500,000$, Marshall Aid is equivalent to an increase in our industrial production of 7 per cent as a first approximation". Among points which arose in discussion were the problem of plant valuation and the need for individual firms to give more thought to the question of labour incorporated in capital equipment. The report may be obtained from the British Institute of Management, 17 Hill Street, Londgn, W.1, price $2 s$. $6 d$.

\section{Abstracting Journals}

A List of Periodicals and Bulletins containing abstracts published in Great Britain has been prepared under the supervision of the Abstracting Services Cofiph tative Committee and issued by the Royal Sociej (London: Camb. Univ. Press. Pp. 62. 2s. 6 A. NCh periodicals are listed alphabetically by tick win explanatory notes, and there is a further cfas lifiod list under the following heads: agriculture, bdtany, food and nutrition; biology; chemistry, chemical industry and mineralogy; engineering; electrical engineering; medicine; metallurgy ; miscellaneous industries; physics, geology and meteorology. An index to the names of institutions, societies and other publishers is included, and a partial list of journals containing abstracts published in the British Commonwealth is appended. Information on omissions, particularly of abstracting bulletins of industrial concerns, is invited, for possible incorporation in future editions.

\section{Institution of Naval Architects: Awards}

THE Institution of Naval Architects has recently announced the following awards for 1949: 1851 Exhibition commissioners postgraduate research scholarshio in naval architecture ( $\$ 500$ per annum for two years) to I. M. Yuille, University of Glasgow ; Aluminium Development Association research schglarship in the application of light alloys to ship construction ( $£ 400$ per annum for two years) to J. B. Caldwell; Martell scholarship in naval architecture (£175 per annum for three years at the Royal Naval College, Greenwich) to J. W. Goymer, H.M. Dockyard, Sheerness ; Earl of Durham prize, in connexion with the examination for the Martell scholarship in naval architecture, to S. Faulkner, H.M. Dockyard, Devonport. \section{Awards of National Certificates in Textiles \\ OF a total of 298 students who took the examina.} tions this year for the award of national certificates in textile\%, 230 students were successful, 157 having studied cotton subjects and 73 woollen and worsted processing. This is the highest number of successes so far obtained since the inception in 1935 by the Textile Institute and the Ministry of Education of the scheme for the award of certificates. The corresponding number last year was 195, and the highest pre- war total was 186. The awards this year are divided as follows: for the ordinary national certificate, 205 candidates sat and 150 secured awards ; of 93 students seeking the higher national certificate, 80 were successful. The former certificate entails three years of study and the latter five years.

\section{Announcements}

Prof. W. L. WAterhouse, research professor of plant pathology and agricultural botany in the University of Sydney, has been awarded the Farrer Memorial Medal for 1949 in recognition of his work on yheat diseases and their control.

THE Lord President of the Council has appointed the following to the Advisory Council for Seientific and Indust ial Research for five years from October 1 , 1949 : Mr. A. H. Wilson, since 1945 director of researy and development of Messrs. Courtaulds, Ltd.; Mr. A. H. S. Hinchliffe, governing director of Glazebrook Steel and Co., cloth merchants and exporters, of Manchester; Lord Halsbury, managing director of the National Research Development Council ; and Prof. R. S. Edwards, of the London School of Economics, who has recently made a comprehensive study of research associations. The new members succeed Mr. W. F. Lutyens, Mr. W. J. Drummond, Sir Henry Guy and Sir William Halcrow, who have retired on the completion of their appointments.

Mr. N. A. W. LE GRand, until recently secretary and coymercial administrator of Messrs. J. D. P. Whegtley and Co., has been appointed secretary of the British Welding Research Association, in succession to Mr. A. Barker, who has joined the staff of the British Boot and Shoe Manufacturers' Association.

UNDER the auspices of the Linnean Society of London/in conjunction with the Systematics Association, a course of lectures and demonstrations on "The Practice of Botanical and Zoological Classification" will be given in the rooms of the Linnean Society, Burlington House, London, W.1, on the following dates: October 26, November 9, 23, January 25, February 8, 22, March 8 and May 6. The meetings, which are open to advanced students of biology, will begin at 4.30 p.m.

APPROXIM pele thirty-one post-doctorate fellowships will be offered by the National Research Council of Canada for the year 1950-51, eighteen of which will bo awarded in chemistry, three in atomic energy resparch, and about ten in physics. The stipend is 2.820 dollars per annum, tax free, and is supplemented by travel grants for successful candidates from abroad. While appointments at the Atomic Energy Project, Chalk River, are restricted to Canadian citizens and British subjects, applicants of all nationalities are invited for the Divisions of Chemistry and Physics. Application forms (to be received in Ottawa not later than February 15, 1950) can be obtained from the Secretary, Laboratories Awards Committee, National Research Council, Ottawa, Canada, or from the Chief Seientific Liaison Officer, National Research Council of Canada, Africa House, Kingsway, London, W.C.2, England.

Erray JM. In Nature of October 8, p. 606, Prof. S. Zugkerman was incorrectly described as professor of ghatomy and physiology in the University of Bitmingham. Prof. Zuckerman is professor of anatomy; the professor of physiology is Prof. H. P. Gilding. 